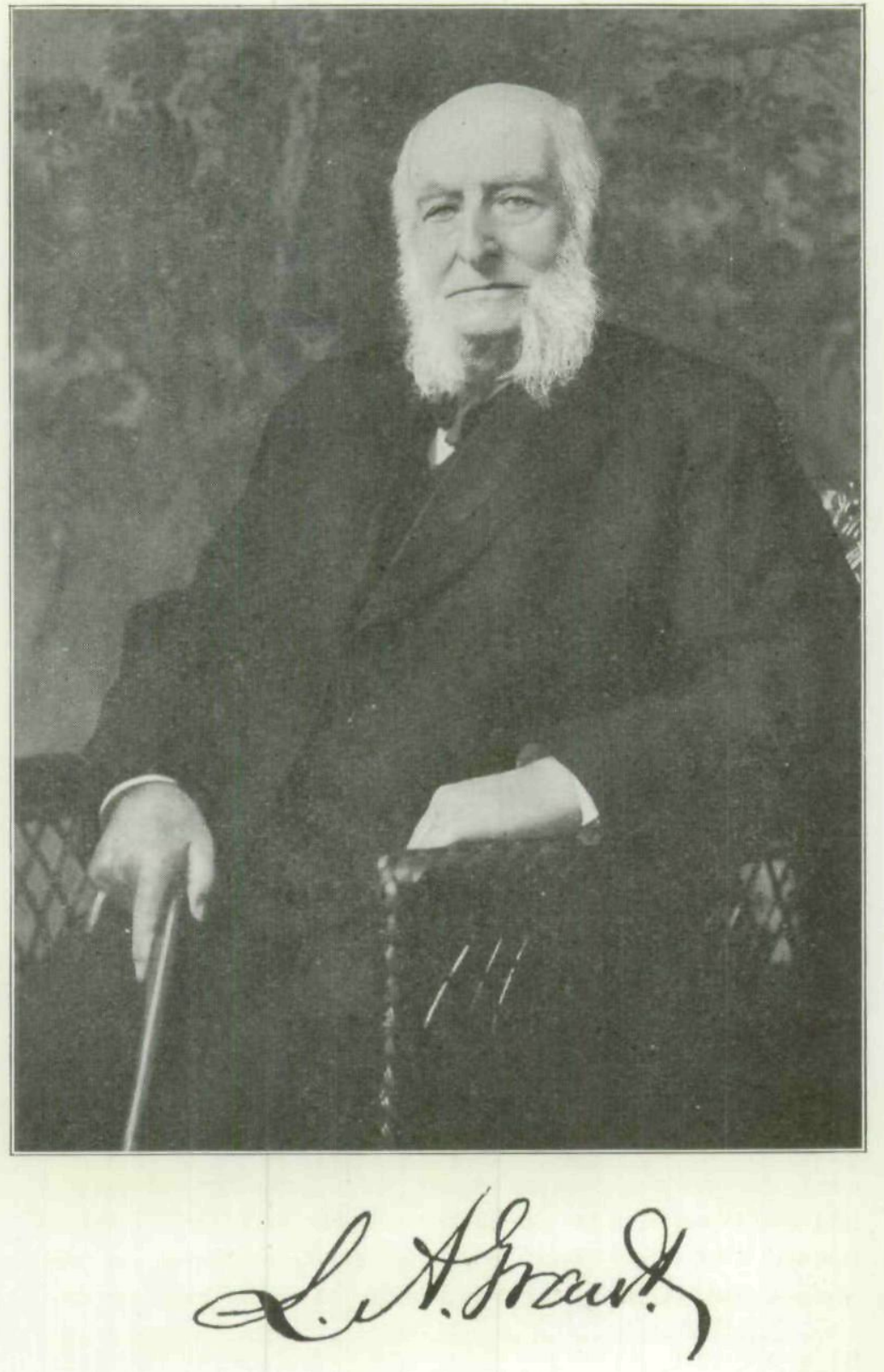




\section{MAJOR-GENERAL LEWIS ADDISON GRANT}

\section{By Charles Keyes ${ }^{2}$}

The real hero of "Sheridan's Ride," and the one personage of all others who made the great fame of that ride possible, appears to me not to have been the commander himself but one of his lieutenants, who, with a relatively small force, had fought and held back an entire Confederate army all day while the rest of the Union regiments were in disastrous retreat. The recent announcement of the demise of that hero recalls the fact that for a quarter of a century he was an honored and distinguished citizen of our state, and was for years one of the most widely known survivors of the Civil War resident in the West.

Major-General Grant, at the time of his death, March 20, 1918, in Minneapolis, Minnesota, at the ripe old age of four score and ten years, was the sole survivor, save one, of the famous Old Vermont Brigade which was one of the most active units throughout the Civil War. Of the many engagements in which he took part two in particular stand out prominently. At the battle of Cedar Creek, Virginia, he saved the Union army from signal defeat. Before Petersburg he planned and led the assault which broke the Confederate lines and opened the way for Lee's surrender seven days later. Subsequently he became assistant secretary of war, and acting secretary of war, under President Harrison.

At the close of the Civil War General Grant resumed his law practice, first in Moline, Illinois, and afterwards at Des Moines. The last mentioned place he made his home for twenty years. At the same time his practice led him directly into land investment. Besides numerous successful city ventures he planned and laid out Waukee, now one of the prosperous towns of Dallas County. The old Grant homestead on Third Street, in Des Moines, still retains its original characteristics and environment. ${ }^{2}$

${ }^{1}$ Dr. Charles Keyes, the writer of this article, was a neighbor of General Grant for many years and talked with him frequently concerning the events herein related, and other phases of the Civil War.-Evrror.

'Business has deeply invaded this once select residence district, but the Grant residence, No. 830 Third Street, is still preserved intact.-EDrror. 
When, in the early eighties, the great real estate "boom" of the Twin Cities set in General Grant invested heavily. His interests in Minnesota occupied so much of his attention that he finally removed to Minneapolis altogether.

Lewis Addison Grant was born in Winhall Hollow, Vermont, January 17, 1829. He was the youngest of a family of ten children. His father, James Grant (1772-1856), moved from Massachusetts to the Green Mountain state in early days and engaged as a school teacher and farmer. His mother, before her marriage, was Elizabeth Wyman (1784-1875), of Lunenburg. Massachusetts, daughter of David Wyman, a Revolutionary soldier. The original Grant ancestor in this country was Christopher Grant (1608-1663), who emigrated from Scotland in 1630, and settled in Watertown, Massachusetts.

The boyhood of Lewis was spent in the usual strict ways of the old New Englanders. He attended the district school of Townshend, Vermont, until he was sixteen years of age. The following year he taught in this same school where the term before he had been pupil. Later he attended the academy at Chester, Vermont. After academy days he taught school for a period of five years in New Jersey, in Chester, Vermont, and near Boston, meanwhile reading law. He was admitted to the bar in 1855 and began the practice of the law in Bellows Falls, Vermont.

On March 11, 1857, young Grant was united in marriage with S. Agusta Hartwell, of Harvard, Massachusetts. To them a daughter was born, now Mrs. George W. Stone, of Indianapolis, Indiana. Mrs. Grant died January 27, 1859. Four years afterwards, on September 9, 1863, Mr. Grant married Mary Helen Pierce, of Hartland, Vermont, a niece of President Franklin Pierce. Their two sons are Captain James Colfax Grant, a prominent attorney of Minneapolis, Minnesota, and Dr. Ulysses Sherman Grant, now dean of the College of Liberal Arts in Northwestern University, at Evanston, Illinois, and a distinguished scientist of more than national reputation.

Under the firm name of Stoughton \& Grant, at Bellows Falls, Vermont, the junior member had hardly entered his professionaI career when the Civil War came on. He at once gave up his law practice and joined the colors. 
Lewis A. Grant was commissioned major of the Fifth Vermont Infantry Volunteers, which was mustered into service September 16, 1861, at St. Albans, Vermont, to serve three years. This regiment was assigned to the Army of the Potomac and participated in the advances of that organization during the spring of 1862. He was mustered into service as lieutenant-colonel of the same regiment on September 25, 1861, and was promoted to colonel on September 16, 1862. He was honorably discharged as colonel on May 20, 1864, to enable him to accept an appointment as brigadier-general of volunteers. In the latter part of the same year he was commissioned major-general of United States volunteers by brevet to date from October 19, "for gallant and meritorious service in the present campaign before Richmond, Virginia, and in the Shenandoah Valley," and was honorably discharged from the service August 24, 1865. In July, 1866, he was appointed lieutenant-colonel of the Thirty-sixth Infantry, U. S. Army, but after his four years of hard service, storm and turmoil, he preferred private life and declined the honor.

General Lewis A. Grant was one of the most distinguished soldiers of the Civil War, and his military services were conspicuously valuable. His service covered practically the whole period of the war, during all of which time he was in command of the regiment, brigade, or division to which he belonged. $\mathrm{He}$ was twice wounded in battle, once in the leg at Fredericksburg, December 14, 1862, and again in the head at Petersburg, April 2, 1865. For distinguished gallantry in the battle of Salem Heights, on May 3, 1863, congress awarded him a medal of honor.

As shown by the records of the war department General Grant took active part in many engagements, the most important of which, with his brigade, are as follows: Yorktown, May 5, 1862; Golding Farm, June 28, 1862; Savage Station, June 29, 1862; White Oak Swamp, June 30, 1862; Crampton Gap, September 14, 1862; Antietam, September 17, 1862; Fredericksburg, December 13 and 14, 1862. As brigade or division commander he was in the following battles: Fredericksburg and Salem Heights, May 3 to 5, 1863; Gettysburg, July 2 and 3, 1863; Fairfield, July 5, 1863; Rappahannock Station, November 8, 
1863; Mine River, November 27, 1863; Wilderness, May 5 to 7 , 1864 ; Spottsylvania Court House, May 8 to 21, 1864; Cold Harbor, June 1 to 12, 1864; siege of Petersburg, June 18 to July 10, 1864; Charleston, August 21, 1864; Gilbert Crossing, September 13, 1864; Cedar Creek, October 19, 1864; siege of Petersburg, December, 1864, to April, 1865; assault on Petersburg, April 2, 1865 ; Sailor Creek, April 6, 1865.

General Lewis A. Grant commanded the Second Brigade, Second Division, of the Sixth Army Corps from February 21, 1863, to December 29, 1863; from February 2, 1864, to September 29, 1864; from October 8, 1864, to December 2, 1864; from February 11, 1865, to February 20, 1865; and from March 7, 1865, to June 28, 1865. He commanded the Second Division of the Sixth Army Corps from December 2, 1864, to February 11, 1865.

The new Fifth Vermont organization was mustered into regular service in September, 1861, at once went to Washington, where it joined the Army of the Potomac. Upon uniting with the Army of the Potomac the Fifth Regiment was brigaded with four other Vermont regiments and later with two additional ones from the same state, and served throughout the war as one of the few brigades composed exclusively of regiments from the same state.

Bcause of the fact that this brigade was prominent in practically all of the campaigns which were conducted back and forth through Virginia and Maryland it soon became famous as the "Old Vermont Brigade." All through the desperate fighting on the Peninsula in 1862 the Vermonters were conspicuous for their bravery. At Antietam and later at Fredericksburg this brigade saw active work. In the following spring, at the Second Battle of Fredericksburg, which was fought as a detail of the Battle of Chancellorsville, the brigade, which General Grant was then commanding as senior colonel, bore a severe part. It was for his part in this action that General Grant later received from congress a medal for bravery.

sCaptain B. C. Ward, of Des Moines, who was a member of the Second Ver"Captain B. C. Ward, of Des Moines, who was a member of the second Ver-
mont Infantry, one of the regiments of this brigade, tells the following anecdote: "At one time when our regiment was occupying quarters near the Twentysixth New Jersey, we were missing things a great deal. We finally killed and sixth New Jersey, we were missing things a greared a dog and placed the carcass where it could be seen, and in the morning

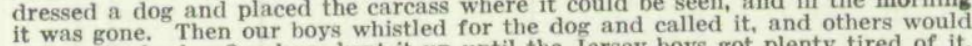
imitate its bark. Our boys kept it up until the Jersey boys got plenty tired of it,
but they seemed to 'catch on, if they hadn't already because of the quality of the meat, and our things were not molested so much after that." 
As the Battle of Gettysburg began General Grant and his Vermont brigade, which was still a part of the Sixth Army Corps, was at Mt. Airy, Maryland, thirty miles from the field of action. Breaking camp at one o'clock in the morning and marching all day they reached the battle ground just before sunset, and took up position on Little Round Top. Had General Lee followed the advice of Longstreet the burden of the great assault made by Pickett, on the following day, would have fallen upon this brigade instead of the center. Lee's decision saved them from this fate.

Fifty years afterwards, at the grand reunion held on the battlefield on the anniversary of the Battle of Gettysburg, General Lewis A. Grant, General Daniel E. Sickles, and General John R. Brooke, of the Union Army, and General E. M. Law, of the Confederate Army, were the only surviving general officers of the forces engaged, and all four were present. Congress had done a gracious act by appropriating funds to cover all traveling and other expenses of all the soldiers of both armies who had participated in this, the decisive battle of our Civil War.

The position of General Grant's First Vermont Brigade on Little Round Top on that fateful day in July, 1863, is marked by one of the finest of the many handsome monuments erected on the field of Gettysburg. It is known as the "Vermont Lion." When acting secretary of war during the Harrison administration, in 1893, General Grant with his family visited the spot. In the accompanying view of the Lion (see illustration) the personages are General Lewis A. Grant, Mrs. Grant, his son, Doctor Grant, and the latter's wife, Mrs. Avis Winchell Grant.

When General U. S. Grant came from the western armies to take command of the Army of the Potomac the "Old Vermont Brigade" was one of the strongest and most dependable contingents. In the Battle of the Wilderness, than which the annals of history show no fiercer nor more sanguinary fighting, the Vermonters were called upon to occupy one of the most important positions on the entire line, and for many hours they held off the attacks of two entire divisions of Hill's Confederate Army Corps. 


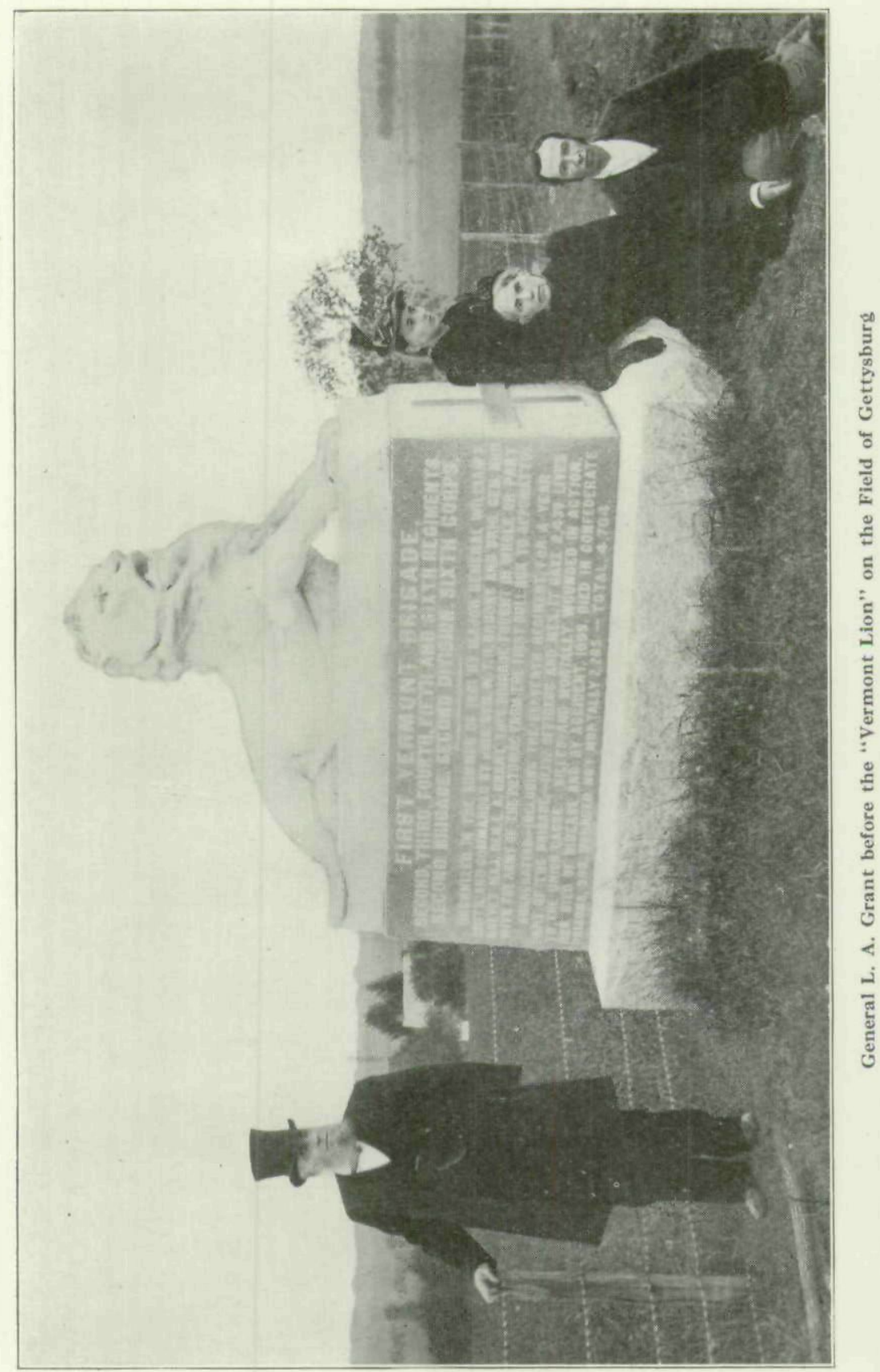


In 1864, when the city of Washington was menaced by Early, a call came to the commander-in-chief to send some of his most trustworthy troops to the defense of the national capital. Among those hurried forward was the "Old Vermont Brigade." The same brigade was among the picked troops which Sheridan took with him to follow Early back up the Shenandoah Valley. The fame of this brigade increased with the passing of each year of the war. Not the least record of the many proud deeds written in its history was the part it took in October, 1864, at the battle of Cedar Creek, Virginia.

For the important and conspicuous part taken in the fighting at Cedar Creek, when Sheridan, galloping from Winchester, twenty miles away, turned a defeat into victory, General L. A. Grant was commissioned a brevet major-general of volunteers. It was his "Old Vermont Brigade" which saved that day.

During the draft riots in New York towards the close of the war, when the metropolis was facing anarchy, the governor of the state sent a hurry call to Washington for troops to protect the city from property destruction and murder. "I want men who can be absolutely trusted," was the word that went forward. The "Old Vermont Brigade" was sent in reply.

The Battle of Cedar Creek, or Belle Grove as it was known in the South, was one of the famous engagements of the Civil War. By it Early was silenced, danger of rebel raids in the North was eliminated, Lee's commissary was greatly curtailed, and a speedy end of the war was brought into vision. Although it was often told in story and song, and was voluminously written of in prose and poetry, the battle itself was never very well understood, particularly in the North. Stories were repeatedly told of the stealthy approach of the Confederates in the darkness just before dawn, of how they relieved our picket lines and without hinderance walked into our camp, of Sheridan's magic power in checking disaster of a thoroughly disorganized army and in leading it back to victory. Popular conception had it that our troops had been caught asleep, that they were captured in their tents, or driven from camp half clad and that Sheridan rallied them into line, marched them back and turned the tide of battle.

Notwithstanding the fact that many of these tales are untrue, when well told they prove rather fascinating. Perhaps there is 
enough imagery in them to warrant poetic license and undue exaggeration to be indulged in; but there is not much poetry or fiction about the battle itself. That is real and terrible. Its history presents an instructvie study of strategy, valor and discipline. Stripped of all its embellishments the relation of the events is not altogether uninteresting. General L. A. Grant's own version throws many side lights upon the episode that have not yet appeared in the histories. It gives us some new ideas concerning this decisive action.

It is recalled that Sheridan had pursued Early up the Shenandoah Valley and that his army was encamped on Cedar Creek, when he was called to Washington. During his absence the Confederates were not idle. Early's condition was somewhat desperate. Since the destruction of his supply train and his cattle and forage he could no longer subsist at Fisher Hill where he then was. He must give battle or fall back. He decided to fight. This attack he began before daylight.

On the morning of the battle a dense fog hung over the valleys making a comprehensive view of the situation impossible. In the obscurity and excitement of the early attack there was some confusion of orders and movements on part of the Union forces. They fell back and continued their retreat for a distance of four or five miles. It was there that Sheridan found them on his return from Winchester. The entire Eighth and Nineteenth Corps and two divisions of the Sixth Corps were thus effectually disposed of and were out of the fight.

The Second Division of the Sixth Corps was the only force which was not in flight. It stood its ground. On it fell the brunt of the day's engagement. This unit was universally known as Getty's division, having been long under the command of General George W. Getty. When the attack commenced, the Sixth Corps was commanded by General Ricketts. General Getty was in charge of the Second Division, in which General L. A. Grant commanded the Second, or Vermont, Brigade. Early in the action Ricketts was wounded, and the command of his corps devolved upon Getty, while the command of the latter's division fell upon Grant, they being respectively the next officers in rank.

On the night before the battle the Second Division of the Sixth Corps went into camp on the right and rear of the Union infan- 
try at a point two miles from the place of first attack. This division constituted no part of the Union lines before the battle. No other infantry fought with it during the battle in the morning. Not until late in the afternoon, after Sheridan came upon the field, was it supported. This division was separated from, and acted independently of, all other infantry during the operations of the morning and independently of all other commands, except a division of cavalry to the left and a small squad of artillery men with two guns.

The Second Division was under arms early in the morning and marched promptly to the left to a position near Middletown in the direction of the firing. By this movement the division became the left wing of the infantry of the army. It found itself directly in front of the advancing Confederates. The Vermont Brigade reached this position first, and, immediately throwing forward a strong line of skirmishers, it advanced to the pike, on the high ground south of the village, where it checked the enemy's progress until Pegram's division, coming fresh upon the field, attacked, and drove it back. While this was going on General Getty moved the Second Division about 300 yards to the left of where it first formed and somewhat to the rear, to an elevation, or crest, of a semicircular hill.

Curiously enough General Early thought that he had encountered and defeated an entire Union division. In his account of the events of the morning, as stated in his "Last Year of the War" (page 106) he observes: "Gordon pushed his attack with great energy, and the Nineteenth and Crook's corps were in complete rout, and their camps, with a number of pieces of artillery and a considerable quantity of small arms, abandoned. The Sixth Corps which was on the enemy's right, and some distance from the point attacked, had had time to get under arms and take a position so as to arrest our progress. General Gordon briefly informed me of the condition of things, and stated that Pegram's division, which had not been previously engaged, had been ordered in. He then rode forward to take command of the division and I rode forward on the pike to ascertain the position of the enemy, in order to continue the attack. There was now a heavy fog, and that, with the smoke from the artillery and small arms, so obscured objects that the enemy's position 
could not be seen; but I soon came to Generals Ramseur and Pegram, who informed me that Pegram's division had encountered a division of the Sixth Corps on the left of the Valley pike, and, after a sharp engagement, had driven it back on the main body of that corps, which was in their front in a strong position."

In this opinion General Early was badly mistaken, since it now turns out that the "division" which Pegram encountered, and, "after a sharp engagement, had driven back," was simply the skirmishers from the Vermont Brigade. The impression which the brigade made upon the enemy so that it was magnified into a whole division amply attests its activity on this occasion. It was pushed back, but in the process it brought with it a considerable number of Confederate prisoners. No other division of the Sixth Corps was on that part of the field.

During the brief space of time when the Second Division was taking its new position on the crest of the hill and the enemy was getting ready to attack, there was opportunity to obtain a hasty view of the situation. The hill erest was not a high one, but it was sufficiently elevated to be clear of the fog which existed only on the low lands.

It is not necessary here to dwell upon the details of the disorderly flight of the bulk of the Union Army on the occasion of Cedar Creek. For the expected attack the Second Division, which alone stood its ground, had not long to wait. The onrush came with the vigor and persistence of an army flushed with victory. It was met by a terrible musketry fire along the entire line. The attacking forces were completely repulsed and thrown back in confusion. They reformed, strengthened their line, and again advanced to the attack. They were again met by a wall of musketry fire. In this second attack they were even stronger and more persistent than in the first. They seemed determined to possess themselves of the hill crest. Some of them came up through a little cemetery and the brush adjacent, within a few paces of the Union line, and there met death. Again were they completely repulsed, and their lines driven back in confusion, leaving the Vermont front covered with dead and wounded. In their precipitous withdrawal they were closely followed by a skirmish line from the Vermont Brigade. At this point Early 
brought his artillery into action and opened up a savage fire. The distance being short and the range quite accurate the fire was at first very destructive. General Bidwell and other officers were killed and many of the men wounded. Yet the Union line was not broken or greatly disturbed. By hugging the crest most of the missiles went overhead. Early was mistaken in supposing that his artillery drove the Union forces from the hill crest. It did not. The attack was endured for fully half an hour when there was another infantry advance. This third attack was not so vigorous nor so sustained as the former ones. The attacking line was much longer than the defending line and extended far to the latter's right. General Getty was in a position to see that the extended line of the enemy had come round the woods to the right of his own troops and was threatening the rear. $\mathrm{He}$ at once gave orders to fall back. This was accomplished deliberately, and a skirmish line was left on the crest, which held the position until long after Sheridan arrived on the ground, and until the whole Union Army moved forward to an attack late in the afternoon. The Second Division formed a new line along a fence and a stone wall, with its left resting on the pike. This it continued to hold. The enemy did not seem inclined to disturb it very much. The Second's skirmish line repulsed all attacks or pretended attacks. It was on this line that Sheridan found the division. It was from this line that the general attack in the afternoon was made, which resulted in driving the enemy from the field and in the capture of many prisoners, guns and ambulances and large quantities of ammunition and supplies. The line which the Second Division selected for the final stand was about one mile from Middletown. In this position it held the front until Sheridan came, and long after. In his "Memoirs" (II, pp. 82-83) Sheridan states that when he arrived at the front "This division and the cavalry were the only troops in the presence of and resisting the enemy." Sheridan flashed upon the field like a meteor athwart the sky. Unheralded and unexpected, he dashed down the pike at the full speed of the noble animal upon which he was mounted. Suddenly wheeling to his right, he galloped along the rear of the line, darted through an opening made for him in the Vermont Brigade, pulled up abruptly in its front and commanded, "What troops are these?" "The Vermont Brigade," 
"The Sixth Corps," were simultaneously shouted from the ranks. "We are all right," replied the General. Then quickly turning, he rode rapidly off to the right amidst the tremendous cheers of officers and men.

The effect was indeed electrical. Sheridan's presence inspired all with courage and enthusiasm. He soon appeared upon a swell of ground in the rear. With him was General Wright. Corps, division and brigade commanders quickly gathered about him. His practiced eye and keen intellect at once took in the whole situation. He decided to assume the offensive. Immediately he sent for the First and Third Divisions of the Sixth Corps and the part of the Nineteenth Corps which he had passed near Newton. When these came up he placed them on the right and in extension of the line formed by the Second Division. He also made some slight changes in the position of the cavalry. As they came up he sent the scattered forces of Crook's Corps to the left of the pike. Since the Nineteenth Corps and the First and Third Divisions of the Sixth Corps had three or four miles to march from the rear it was late in the afternoon before everything was ready for the advance movement.

After the Second Division had established its second and permanent line, part of the Third Division, Sixth Corps, and a small force from the Nineteenth Corps, apparently parts of three or four regiments, took position on the right of the line, and repulsed a demonstration, or feint, made on its front in the afternoon. General Hayes also reported to General Getty some small detachments from regiments of the Eighth Corps which had preserved their colors. This was the small force referred to by Sheridan as seeming to rise up out of the ground. From whence these small detachments came into line no one can say. They were not on the hill crest in the morning.

When Sheridan arrived on the field he brought with him one man, and one only. The other members of his staff and escort were strung out along the pike in the rear as far as eye could reach, all making desperate efforts but failing to keep up. One mounted orderly, with a horse of very ordinary appearance, kept "closed up." When the General halted in front of the Vermont Brigade this man swung around to his proper post in 
the rear. That orderly ought to be known that he, too, and his horse might be immortalized. General Grant relates an amusing anectode how, in after years, he endeavored to locate this orderly who had participated in Sheridan's Ride. In the final results he found three letters, from as many persons, each one claiming the honor. Which one it was, if any one of them, still remains in doubt.

About four o'clock in the afternoon the whole Union Army advanced all along the line. The enemy's stand was assailed vigorously. At several points he was strongly protected by stone walls, causing some delay and considerable severe fighting. Nevertheless he was finally driven from these strongholds. Then there was another general advance. There was but one more halt and that was of short duration. The Union troops rushed forward and drove the enemy before them. Soon the Confederate Army was in full retreat, which presently developed into a rout and a stampede.

The northerners pressed forward to their utmost speed. The advance was taken by the strong of wind and fleet of limb. Many Confederates were overtaken and captured; the rest were driven off the field and beyond Cedar Creek where the cavalry continued the pursuit. First among the infantry to reach the creek was the advance runners of the Old Second Division. Others of this unit were not far behind and they came forward into line as the front began to slow down. It was now quite dark. The tired but victorious troops then marched back to the position of its morning camp and went into bivouac for the night.

The Confederates succeeded in getting away with most of the prisoners which they had captured in the morning, but they lost about the same number of their own men as prisoners. The Union forces recaptured all of their lost guns, and took all of the Confederate artillery, ambulances and supply trains. Early's army was practically destroyed. It ceased to be an effective organization.

It now seems clear that it was Getty's division alone which repulsed and held back Early's army on that October morning and that it, rather than the Sixth Corps, is entitled to full credit. This division was not probably superior to all others. It chanced 
not to be placed in so unfortunate positions as Thoburn's division and the Nineteenth Corps, and under such circumstances it might not have done any better than they did. As a matter of fact there was not very much that they could do. With the enemy rapidly advancing in their front, on their flanks and even on the rear, they had to get out of their bad predicament the best way they could. It may be, also, that the First and Third Divisions of the Sixth Corps had good reason to fall back four miles. The Second Division was lucky. It was so situated that it had time to form in line, to select position, and so to check the enemy's advance. It realized its opportunity and improved it. Other troops might have done quite as well. None could have done better.

It is interesting to note what could not have been foreseen at that time, that in the Eighth Corps of two small divisions which had been so panic-stricken and scattered that morning there were two future presidents of the United States, General Rutherford B. Hayes and Major William McKinley.

Immediately after the Battle of Cedar Creek the Vermont Brigade returned to its post before Petersburg, Virginia, and continued to take part in the siege of that place until its fall and the close of the war.

Concerning General Lewis A. Grant's assault on the Petersburg fortifications on April 2, 1865, Lieutenant-Colonel Merritt Barber, assistant adjutant-general of the U. S. Army, communicates the principal data in substantially the following language:

With a desire to add a few facts to the history of the Old Vermont Brigade in its conduct during the great struggle for national existence and to place proper credit to its able commander, which he himself appears to have been too modest to assume, it is my purpose to put on file a statement in regard to an incident in General Lewis A. Grant's command of the brigade of which I am probably the only one, except himself, who is familiar with the details. It is in connection with the assault on the rebel works in front of Petersburg on the morning of April 2, 1865, in which the brigade led the attacking columns and bore such a conspicuous part. The incident is briefly outlined in Benedict's "Vermont in the Civil War"; but it is not there so fully stated as to give the brigade commander his due credit for the splendid achievements of the brigade on that occasion.

'Colonel Barber was Gen. L. A. Grant's adjutant-general in the Civil War, and was an eye-witness of the attack. 
It will be remembered that throughout the terrible Wilderness campaign of 1864 the brigade under his command had written a chapter of renown on every bloody battlefield from Brandy Station to Petersburg, had hastened to Washington in July to repel the attack of Early's rebel army upon the national capital, had continued its brilliant record in every engagement with Sheridan in the Shenandoah Valley and had returned to its place in the Petersburg lines in December. During the

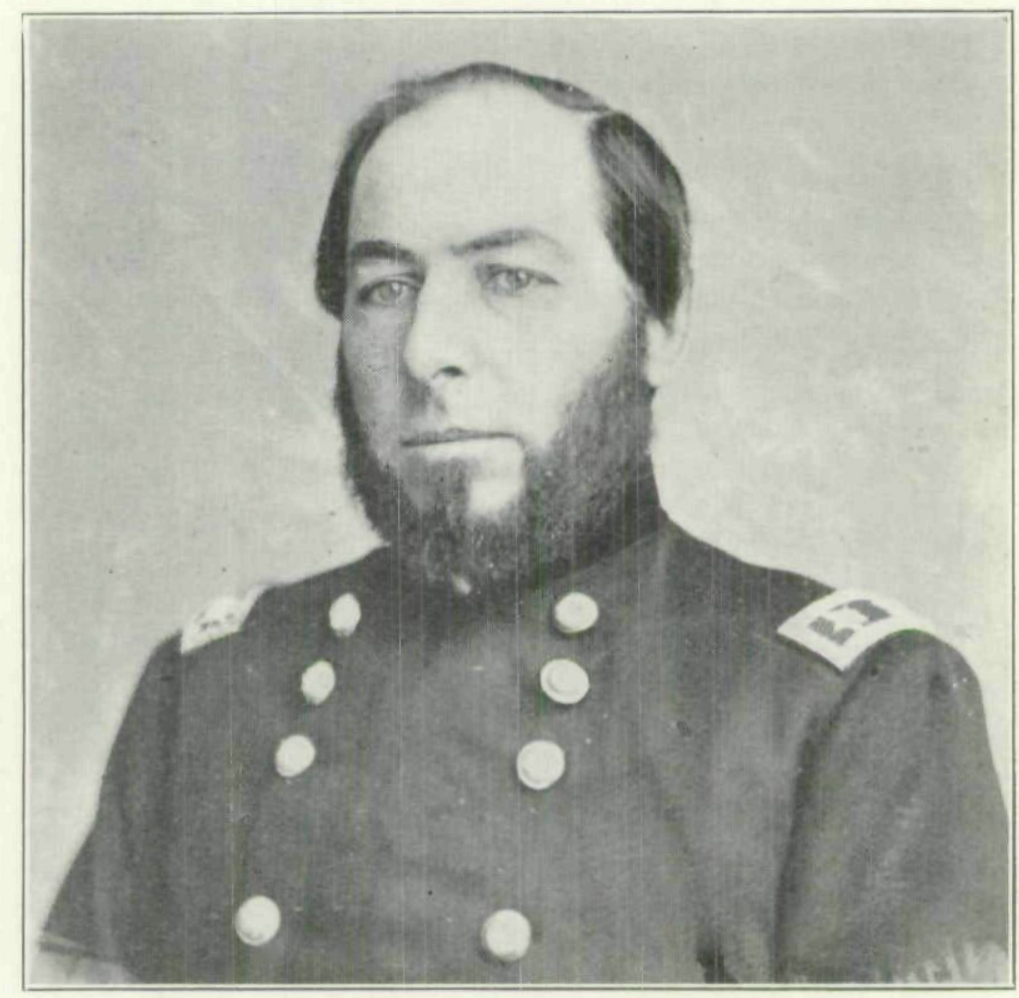

MAJOR-GENERAL LEWIS A. GRANT

absence of the brigade in the Shenandoah Valley, the Army of the Potomac had made repeated but unsuccessful attacks on the lines covering Petersburg and Richmond, so that upon the return of the Sixth Corps to that army the feeling seemed to prevail that those lines were impregnable. Not so with the Sixth Corps.

Accustomed to victory the Sixth Corps could not conceive defeat, and it looked upon the massive works frowning in front as its legitimate and confident prey. At this juncture, too, it was evident to all that the 
coming event would be the final struggle of the war. No one was more fully alive to this anticipation than General L. A. Grant. . To prepare himself to take the part in that event which the Vermont Brigade had always so conspicuously borne in the achievements of the Sixth Corps, he labored incessantly to put his command in the highest state of efficiency and to familiarize himself with the enemy's lines in order to discover, if possible, some weakness, or circumstance, of which he might be able to take advantage in the impending struggle. For this purpose he made frequent visits to the picket lines and minutely scanned the enemy's works not only in front of his own command, but to a considerable distance on either side in front of adjacent troops.

The engagement of March 25, in which as usual the Vermont Brigade took a foremost part with its customary success, was rewarded by the capture of the enemy's skirmish line and rifle pits which were occupied thereafter by our own skirmishers, and from which, in closer proximity, the General studied the works more advantageously. At length he discovered the opportunity of which the brigade under his direction took advantage so successfully on the morning of April 2. This was a space of twenty-five or thirty yards in the enemy's line, which was unprotected by earthworks, ditches or abatis, and which was occasioned by a shallow ravine running directly through the works and occupied by the channel of a little brook at that season of the year nearly, if not quite, dry. On both sides of the brook the works were turned a short distance to the rear and guns were planted in the turning angles on either side.

On the right and left of the ravine the General also discovered passageways across the broad, deep ditch in front of the works, evidently prepared for the crossing of skirmishers and such other services as were necessary in front of the lines. The passageway on our left hand appeared to be sufficiently substantial for the crossing of an attacking column; that on our right was simply a number of stringpieces, or small logs, not covered with poles and brush, as was that on the left, but could be used to some advantage. The abatis a short distance in front was discovered to be broken in many places and not to present any serious obstacles to passage. Carefully noting these facts, the General concluded that it was feasible to carry the works at this point. $\mathrm{He}$ communicated his views to the division commander, General Getty, who at his request went out with him to examine the place himself. Subsequently, at the suggestion of General Getty, both the corps commander, General H. G. Wright, and the army commander, General Meade, went down with General Getty to examine it, and in company with General L. A. Grant they all looked over the ground together. General Grant pointed out to them his discoveries and the opportunity which, in his judgment, the situation offered for successful attack. His views were adopted by the commanding generals and they decided that the attack should be made at that place. Following quickly this decision the time for action came. 
Sometime during the forenoon of April 1 General L. A. Grant was informed that at four o'clock the next morning the attack would be made by the corps formed en echelon of brigades massed in columns of regiments. The Second Division was selected to lead the corps and the Vermont Brigade was chosen to head the division. He was directed to move out with his brigade at midnight and take position, being informed at the same time that the other two brigades of the division would form to his right and rear and two additional divisions would form on the right and left and to the rear of the Second, thus giving the point or entering wedge of the echelon, as the post of honor, to the Vermont Brigade in recognition of the eminent sagacity and judgment displayed by its commander in discovering and seizing the proper line of action for this great undertaking.

No specific orders for making the attack were given. General Grant was to select his own ground and his own point and method of attack and the remainder of the corps were to be guided in their action by the movements of the Vermont Brigade. During that afternoon the General again went out and carefully examined the ground so as to be able to take his position in the night time, and, returning to the brigade, he gave instructions on the formation of the column. The arrangement of regiments from front to rear was ordered as follows: Fifth, Second, Sixth, Fourth, Third, Eleventh, in two lines. The regimental and company commanders were assembled at brigade headquarters. Instructions were given to them by General Grant personally that the brigade would be placed for assault directly in the rear of the skirmish line with its left in the direction of the ravine, that when the signal was given the charge should be made in silence, that the left flanks should closely hug the ravine throughout the entire distance to the works and that those to the right should be guided thereby was emphasized as a feature of vital importance. The crest upon which the rebel General Heath's headquarters flag could be seen distinctly was pointed out as the place of assembly inside the enemy's lines and for re-formation there in the order of original formation for the charge. The leading regiment, the Fifth, was to press directly along the ravine, through the works to the crest, and halt there in line as a rallying point for the brigade; the next, the Second, was to follow the Fifth to the entrance of the lines, turn to the right, capture the guns and clear the works on that side, then press forward to the crest and form in rear of the Fifth; the next, the Sixth, was to follow the Second, capture the guns and clear the works on the left of the ravine, then continue forward to the crest, and there form in place; the Fourth was to pass the abatis, turn to the left, and cross the ditch by the bridge on that side, scale the works in front, push on to the crest, and take its proper place; the Third was to do the same on the right, and the two battalions of the Eleventh, each a separate organization, were to push up through the ravine, give assistance on either side to those in front whenever needed, and take their places with the columns on the crest. As already stated these in- 
structions were given to all the regimental and company commianders and they were directed to communicate them to their noncommissioned officers and men, so that at the moment of action a compact body of two thousand five hundred men should move as one, and that one, the veteran "Vermont Brigade." Every man knew just where he and his comrades had to go and what each had to do, and with that knowledge they had the disposition to do it. It was a striking application, more than thirty years ago, of the modern theory of the independent, or individual, system for fighting the battles of the future.

Execution followed the instructions given as closely as the events of battles permit. In passing through the darkness over the rough intervening ground studded with stumps and clumps of alder bushes, intoxieated with the mad rush of the charge and inspired by the cheers of their thousands of companions, it is surprising that the brigade reached its goal, nearly half a mile distant, with any formation at all. It would not have done so if it had not been for the brigade commander's thorough knowledge of the undertaking and his detailed instructions to the troops. The result accomplished was, to the letter, what those instructions required, and if, by some emergency, any organization omitted any part of that which it was charged to do, its neighbor, who had opportunity, took it up and did it instead, as each was familiar with and interested in the tasks of its comrades as well as its own. This was to the personal and individual eredit of General L. A. Grant and it was the very touchstone and keynote of the crowning success of the Vermont Brigade on this glorious occasion.

As the sun rose on that April morning it glistened and danced upon the burnished muskets of those twenty-five hundred Vermonters, a hedge of steel manned by intelligence, standing shoulder to shoulder, seven lines deep, upon the hill crest which had been an hour before the rebel General Heath's headquarters. To the right of them and to the left of them the cannon roared and thundered in continuing conflict, glittering bayonets formed over them a halo of glory for this their last and most brilliant achievement during the War of the Rebellion.

In all his references to this engagement General L. A. Grant speaks of not having participated in it. To be sure he was wounded in the head when by my side near the picket line and was taken to the rear just a few minutes before the charge commenced; but the foregoing narrative of facts will evidence that he participated actively and efficiently in the crowning success of that occasion, and is entitled to the full credit of the success of the operations, at least up to the time when the brigade stood in full array upon the hill crest inside the enemy's lines. The succeeding events of that day were in connection with entire corps, and although filled with daring and brilliant incidents, they derived no inspiration from any one superior commander. Each organization promptly seized the opportunity that presented itself and delivered its blows with a dash and individuality that the situation demanded. But the principal event, the assault and penetration of the Petersburg lines, was 
primarily due to the genius of General L. A. Grant, supported by the Vermont Brigade.

As one of the best known survivors of the Civil War resident in the middle west, General Grant was a familiar figure in his home city down to within a few weeks of his death. As the days of the great storm receded his presence was more and more in demand at the veteran eamp fires, the G. A. R. gatherings and the meetings of the patriotic orders. For years the state of Vermont honored him as the single surviving figure among the many whose names are linked with the organization which holds the proudest post in the records of the old New England province.

General Grant's last visit to Vermont, in November, 1906, was an event long to be remembered by all natives of the Green Mountain state. Invited to the capital city of his birth state as the guest of the commonwealth, he was accorded rare and distinguished honor by its citizens. The invitation to General Grant came through both bodies of the legislature. From the date of his arrival at the state boundaries until his departure he was the recipient of the most cordial hospitality extended by officials and citizens alike. General Grant arrived at Essex Junction on the Vermont state line on October 30, 1906. He was met by Colonels Norton and Gibbon of Governor Fletcher D. Proctor's staff, and by Colonel A. C. Brown, of Montpelier. By them and others General Grant was escorted to the capital city where he was received by Governor Proctor who, on behalf of Proctor, who formerly was lieutenant-colonel of the Second Verthe people of Vermont, welcomed him to his native state.

On the following afternoon a joint assembly of the Vermont legislative houses was held, and General Grant was introduced as Vermont's most illustrious soldier. The resolutions adopted by both houses inviting the General to the state were formally read. An address of welcome was delivered by Senator Redfield Proctor, who formerly was lieutenant-colonel of the Second Vermont Regiment of which General Grant was colonel.

At the conclusion of the exercises Governor Proctor held a levee for the purpose of introducing the General personally to each member of the assembly. In the evening a public reception 
was held which was attended by people from all parts of the state. Special railroad rates were made for the occasion. The reception was doubly appreciated by General Grant, since he had opportunity to renew old acquaintances and friendships.

Next day there was a meeting of the Vermont Officers' Association at which General Grant was unanimously chosen president of the organization, which consisted of more than three hundred and fifty members, all officers during the Civil War. The public meeting and banquet of the association was held the same evening and the General responded to a toast.

After his arrival in the Green Mountain state General Grant was fairly deluged with invitations to visit and speak in different cities and towns. Although he put in a strenuous two weeks he could only accept a small number of the invitations received.

General Grant's presence at the periodic gatherings of the patriotic orders became more and more in demand with the passing of the years. His reception on his last visit to Des Moines, on November 12, 1907, was characteristic. The event was really a notable one in the annals of the city. He came as the guest of honor and principal speaker of the evening at the annual banquet of the Loyal Legion of Iowa. His address was charming, illuminating and full of interest to the army members present, and dealt mainly with affairs during the period of civil uncertainty. The function was one long to be remembered. Amidst the profusion of cut flowers and tropical plants with which the table and hall were decorated, after doing ample justice to a delightful menu, the General was at his best. Covers were laid for one hundred and fifty persons.

On this Loyal Legion visit to Des Moines General and Mrs. Grant were guests at our home. The General carried his 200 pounds avoirdupois with wonderful grace, and was as erect in his advanced years as in the strenuous days of the Rebellion. $\mathrm{He}$ retained a degree of vigor and a keenness of eye that men of half his age might well have been envious. After dinner he and my father, Calvin W. Keyes, who was ten years his senior and even more vivacious, commenced to swap stories and to revive old experiences with a zest and care free abandon of school boys, until the room fairly rang with mirth and hilarity that was really shocking to the staid younger generation present. 
When dwelling upon Civil War matters the General always talked unwillingly of his own military distinction, for he was preeminently a gentleman of the old school, who believed in deeds, not words. During all the forty-odd years that I knew him, and heard him time without number, relate most exciting war experiences it was so modestly and impersonally performed that one would not suspect for a moment that he was through all an eye witness or the hero.

The last time that I saw General Grant was a few months before his demise. Captain Colfax Grant took me up to the office to see his father. The General was apparently as hale and as hearty as he was thirty years previous, when he left Des Moines to reside in Minnesota. He was fully alive to the great questions of the day and to the trend of world politics. The fact that on that very morning he had walked down to the office from his home three miles away amply attested the sustained vigor of the typical New England nonogenerian.

At the outbreak of the World War General Grant expressed the greatest confidence in the manhood of America. "Will the young men be willing to see the war through even if it means heavy sacrifice? We old soldiers are carefully watching these young men. We believe they will do their duty when the time comes." How well the old warrior's prophecy was substantiated is only too conclusively demonstrated by the achievements of two millions of our boys in France.

When, on the morning of March 20, 1918, the Angel of Light touched for a moment on the gate at 138 Rustic Lodge Avenue, in Minneapolis, and sounded reveille he found a valiant, Christian soldier, ready, fully accoutered and eager for the long, last forced march.

On the following Sunday special memorial services were conducted in the Westminster Presbyterian church, at which a large assemblage of citizens from the Twin Cities met to pay homage to the name and fame of the renowned warrior. The exercises were in charge of those who had long been most closely associated with the General, and included the G. A. R., the Loyal Legion, and other patriotic and civic bodies. Judge Eli Torrance presided.

Draped on the rostrum of the church was the battle torn headquarters flag of the Second Brigade, Sixth Army Corps, which 
General Grant commanded at the battles of Cedar Creek, the Wilderness, Petersburg, and other notable engagements of the Civil War. His swords, carried in these battles, were placed upon the flag.

Seated on the platform with Judge Torrance was General C. C. Andrews, the only surviving major-general of volunteers. At the close of the war there were several hundred officers of that rank but with the death of General Grant the number dwindled down to a single survivor. General Andrews was then ninety years old.

Governor J. A. A. Burnquist took a leading part in the memorial exercises. Dr. Cyrus Northrop, president emeritus of the University of Minnesota, Judge Torrance, and others spoke at length. Details of sailors from Dunwoody and of soldiers from the Thirty-sixth Infantry attended. Members of the various patriotic orders marched in a body.

\section{CEDAR AND IOWA RIVERS}

These streams still keep up, and at present are in tolerably good navigable condition. The "Piasa" and "Hawkeye" are making trips regularly up them and return with full cargoes of produce. During the past week Iowa City on the Iowa and Rochester on the Cedar have been visited by these boats.-Muscatine-Iowa Democratic Enquirer, June 23, 1849. (In the newspaper collection of the Historical Department of Iowa.) 
Copyright of Annals of Iowa is the property of State of Iowa, by \& through the State Historical Society of Iowa and its content may not be copied or emailed to multiple sites or posted to a listserv without the copyright holder's express written permission. However, users may print, download, or email articles for individual use. 